\title{
High diagnostic value in rheumatoid arthritis of antibodies to the stratum corneum of rat oesophagus epithelium, so-called 'antikeratin antibodies'
}

\author{
CHRISTIAN VINCENT, ${ }^{1}$ GUY SERRE, ' FREDERIC LAPEYRE, \\ BERNARD FOURNIÉ, ', CHRISTIANE AYROLLES, ${ }^{2}$ ANTOINE FOURNIÉ, ${ }^{2}$ \\ AND JEAN-PIERRE SOLEILHAVOUP
}

From the ${ }^{1}$ Département de Biologie Cellulaire et d'Histologie and the ${ }^{2}$ Clinique de Rhumatologie, Hôpitâni Purpan, Toulouse, France

SUMMARY Serum antibodies to the stratum corneum of rat oesophagus epithelium, so-calle $\overrightarrow{\mathbb{d}^{p}}$ 'antikeratin antibodies'*, have been largely demonstrated in rheumatoid arthritis (RA). IgM and IgG antibodies to this epithelium were studied by semiquantitative immunofluorescence in 528 patients with perfectly characterised rheumatic diseases, including 178 with classical or definit RA. Histological analysis of IgG antibodies showed that only antibodies which produce a lineaథ laminated pattern restricted to the stratum corneum (IgG antikeratin antibodies) are highl specific for RA; all the other labelling patterns are not disease specific. By a semiquantitative evaluation of the stratum corneum fluorescence intensity it was shown that the diagnostic valuesot. IgG antikeratin antibodies closely depends on their titre and it was established in objectiv conditions that the sensitivity is $43 \cdot 26 \%$ when the specificity reaches $99 \cdot 14 \%$. A high titre of 1 ig. antikeratin antibodies was actually pathognomonic for RA. Both the histological and sem quantitative analyses showed that IgM antibodies to rat oesophagus epithelium, though freo quently detected, are of no diagnostic value, either for RA or for any other rheumatic disease̊ that was studied. From a review of all the international reports on IgG antikeratin antibodies was found that, to date, 4080 patients, including 1694 with RA, have been assayed for antikerati $\overrightarrow{\overrightarrow{0}}$ antibodies by 11 different research groups. Analysis of all the results obtained under comparable technical conditions showed that IgG antikeratin antibodies constitute the most specifie serological criterion for the diagnosis of RA. Furthermore, it was found that their incidence does: not depend on disease duration: they are present in one third of rheumatoid factor negativ patients with RA, and they seem to be related to disease severity or activity, or both. Theip detection in the diagnosis of rheumatic diseases should become systematic.

Rheumatoid arthritis (RA), like the other nonorgan-specific autoimmune diseases, shows a wide variety of circulating autoantibodies. Among them, rheumatoid factor (RF) is considered as the most characteristic of the disease, but antinuclear autoantibodies and autoantibodies to various tissue antigens, such as perinuclear granules, ${ }^{1-3}$ collagen, ${ }^{4}$

Accepted for publication 12 January 1989.

Correspondence to Dr Christian Vincent, Département de Biologie Cellulaire et d'Histologie, CHU Purpan, Place du Dr Baylac, 31059 Toulouse Cedex, France.

*Authors' note: Research indicates that the so-called 'antikeratin antibodies' are not directly related to keratins, but for clarity the inverted commas have been omitted throughout the rest of the text. smooth muscle, ${ }^{5}$ and intermediate filaments, ${ }^{67}$ have also been described in RA.

Since the report by Young et al in $1979^{8}$ numerous authors ${ }^{2}{ }^{3-17}$ have described, by indirect immuno $\overline{\bar{\tau}}$ fluorescence in rheumatoid sera, antibodies able t $\odot$ label the stratum corneum of rat oesophagus epin thelium. These anti-stratum corneum antibodies generally called 'antikeratin antibodies', ${ }^{*}$ have bee $B$ found to be a more specific marker than the usuar serological indexes of the disease, and their detecE tion has been proposed as a diagnostic test for RA In all these studies, however, the detection thresholds for antikeratin antibodies have beew arbitrarily chosen and this has introduced som 
variation in the results of different authors in the evaluation of the diagnostic sensitivity and specificity of the test.

We studied IgG and IgM antibodies to rat oesophagus epithelium, including antikeratin antibodies, in a large number of serum samples from patients with well characterised rheumatic diseases. Like previous authors we used an indirect immunofluorescence assay, but to determine objectively the diagnostic sensitivity and specificity of antikeratin antibodies we used an original semiquantitative method to study their labelling patterns in detail with regard to the other antiepithelial antibodies. This method permitted accurate grading of the fluorescence intensity without previous choice of a positivity threshold and therefore determination of a precise antikeratin antibody titre-like value. In addition, we investigated relations between antikeratin antibodies and several clinical and serological indexes of the disease. Lastly, we analysed previous international reports and determined the usefulness of antikeratin antibodies in the diagnosis of RA, and their relations with other features of the disease for all the results of tested sera published since 1979.

\section{Patients and methods}

\section{PATIENTS}

From among 3396 serum samples from 1749 patients with rheumatic diseases assayed during the past two years, we selected and studied 528 samples obtained from 528 patients with perfectly characterised diseases according to clinical, radiographic, and biological criteria (Table 1). The patients could be

Table 1 Details of patients

\begin{tabular}{|c|c|c|c|}
\hline Diagnosis & Number & $\begin{array}{l}\text { Age } \\
\text { median (range) }\end{array}$ & $\begin{array}{l}\text { No(\%) } \\
\text { of men }\end{array}$ \\
\hline Rheumatoid arthritis* & 178 & $60(15-86)$ & $32(18)$ \\
\hline $\begin{array}{l}\text { Systemic lupus } \\
\text { erythematosus } \\
\text { Miscelfaneous connective }\end{array}$ & 28 & $48(21-76)$ & $5(18)$ \\
\hline tissue diseasest & 23 & $59(25-79)$ & $4(17)$ \\
\hline Psoriatic arthritis & 40 & $53(26-75)$ & $27(67 \cdot 5)$ \\
\hline Ankylosing spondylitis & 44 & $43(18-79)$ & $30(68)$ \\
\hline Paget's disease & 69 & 70 (37-86) & $40(58)$ \\
\hline $\begin{array}{l}\text { Miscellaneous non- } \\
\text { inflammatory rheumatic } \\
\text { diseases } \ddagger\end{array}$ & 146 & $56(15-83)$ & $69(47)$ \\
\hline Total & 528 & $58(15-86)$ & 207 (39) \\
\hline
\end{tabular}

*Classical: $113(63 \%)$, definite: $65(37 \%)$; rheumatoid factor (RF) $\geqslant 1 / 64$ : 90 (51\%), RF < 1/64: 88 (49\%).

†Including giant cell arteritis (eight), systemic sclerosis (four), primary Sjögren's syndrome (three), polymyositis (two), Raynaud's phenomenon alone (three), and mixed connective tissue disease (three).

łIncluding arthrosis (98), compressive neuralgia (23), and algodystrophia (25). divided into seven groups: group I consisted of those with classical or definite RA according to the 'old' criteria of the American Rheumatism Association ${ }^{18}{ }^{19}$; groups II to V were composed of patients with various inflammatory rheumatic diseases, including systemic lupus erythematosus, miscellaneous connective tissue diseases, psoriatic arthritis, and ankylosing spondylitis, respectively; the two other groups comprised patients with noninflammatory rheumatic diseases: Paget's disease (group VI), arthrosis, compressive neuralgia, and algodystrophia (group VII).

\section{SEMIQUANTITATIVE INDIRECT}

I M M U NOF L U ORES CEN CE

A semiquantitative indirect immunofluorescence technique, derived from semiquantitative methods largely used in histochemical studies ${ }^{20}$ and previously used to investigate autoantibodies to epidermis in normal human sera,${ }^{21}$ was adapted with minor changes to rat oesophagus.

The middle third ${ }^{11}$ of Wistar rat oesophagus obtained from Pel-Freez (Rogers, Arkansas) was frozen at $-30^{\circ} \mathrm{C}$ and stored at $-80^{\circ} \mathrm{C}$ until assay. Cryostat sections $(4 \mu \mathrm{m}$ thick) were fixed by air drying in an airtight box containing silica gel desiccant for one hour at $37^{\circ} \mathrm{C}$ then overnight at $4^{\circ} \mathrm{C}$, without additional chemical fixation. After rehydration in $\mathrm{pH} 7.4$ phosphate buffered saline (PBS) human serum samples diluted 1:10 in PBS were incubated on slides for 30 minutes at $37^{\circ} \mathrm{C}$ in a moist chamber. The slides were rinsed twice for five minutes in PBS and then incubated for 15 minutes at $37^{\circ} \mathrm{C}$ with fluorescein isothiocyanate labelled goat $F(a b)_{2}^{\prime}$ fragments to human IgM ( $\mu$ specific) obtained from Tago (Burlingame, California) or with fluorescein isothiocyanate labelled goat $F(a b)$ fragments to human IgG ( $\gamma$ specific) purchased from Biosys (Compiègne, France), diluted 1:50 in PBS. The slides were rinsed twice in PBS and mounted with Fluoprep medium (Bio-Mérieux, Lyon, France). Observations were performed on an Olympus-BH2 microscope with ultraviolet epiillumination, and photographs were taken with an Olympus-OM4 camera (Tokyo, Japan).

The fluorescence intensity of each histological compartment of the cornified stratified squamous epithelium of the rat oesophagus (Fig. 1A) - that is, stratum corneum, stratum spinosum, and stratum basale, was separately estimated by two readers, who did not know the clinical context. Results were estimated on a semiquantitative scale from 0 to 4 and the results of the two readers were summed (final range $0-8)$. On such a scale the accuracy of the human eye reading has been found to be better than 0.50 (data not shown). Therefore a 0.25 step was 
chosen so that measurement accuracy was not limited by the scale inaccuracy. The reliability of the semiquantitative evaluation was ensured in each assay by a previous reading of three reference sera of known intensity, acting as interassay controls. Moreover, three other known serum samples $\frac{0}{n}$. permitted the stability of the evaluation within each assay to be controlled.
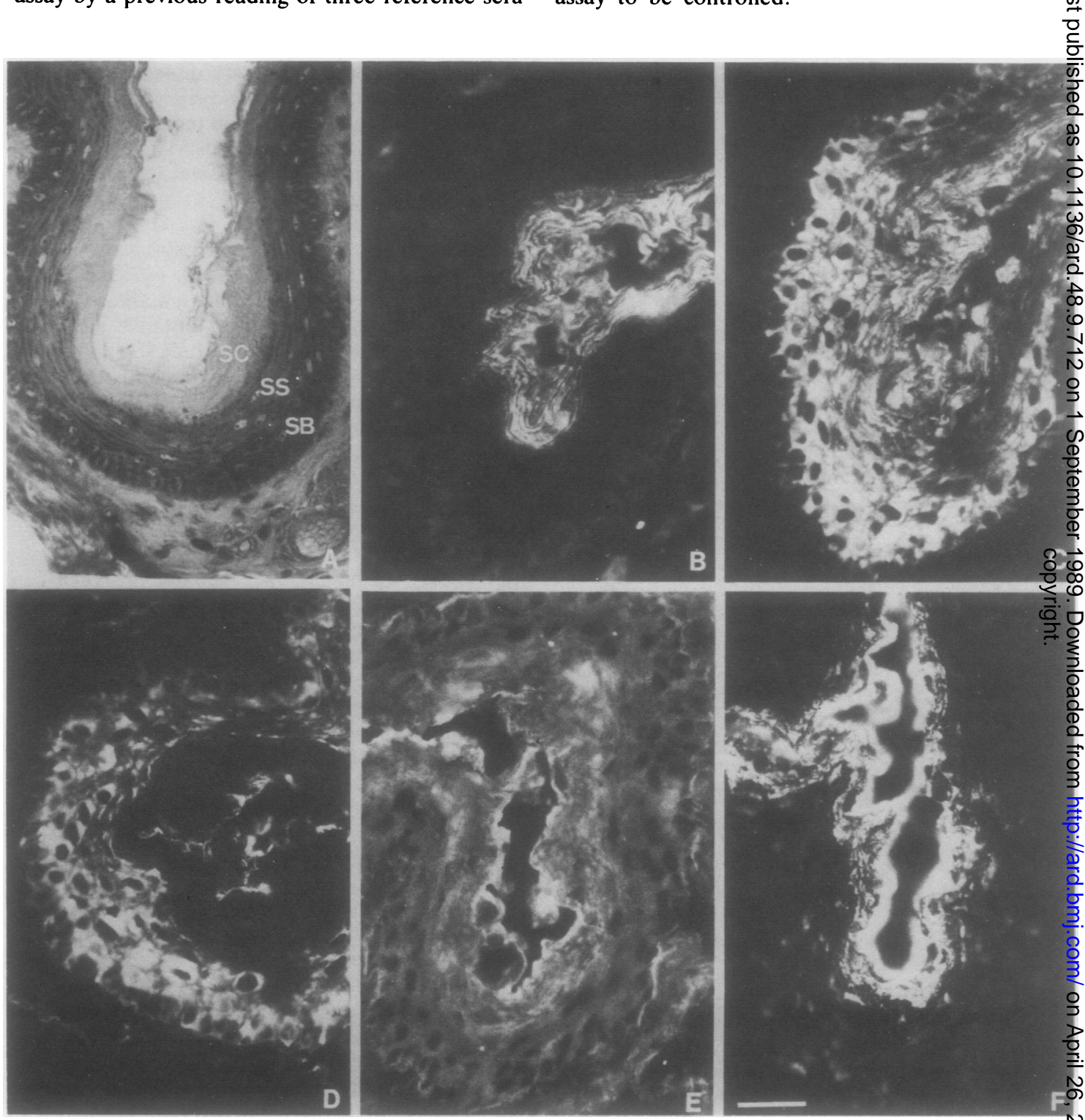

Fig. 1 Histological patterns of labelling produced by $\lg G$ and $\operatorname{IgM}$ antibodies to rat oesophagus epithelium. (A) Histological structure of the cornified stratified squamous epithelium of rat oesophagus: stratum corneum (SC), stratum spinosum (SS), stratum basale (SB). (B) Rheumatoid arthritis specific IgG anti-stratum corneum antibodies 0 (antikeratin antibodies): linear, laminated labelling restricted to the stratum corneum. (C) Non-disease-specific IgG 6 antibodies: intense, diffuse, cytoplasmic labelling of the stratum spinosum and intense laminated labelling of the stratum corneum. (D) Non-disease-specific $\lg G$ antibodies: intense, diffuse, cytoplasmic labelling restricted to the stratum spinosum. (E) Non-disease-specific IgG antibodies: weak, diffuse labelling of the three epithelial compartments. (F) Non-disease-specific IgM antibodies: more or less laminated, heterogeneous labelling of the stratum corneum and weak flaky labelling of the stratum spinosum and the stratum basale. Bar $=40 \mu \mathrm{m}$. 
The morphological pattern of labelling in each epithelial compartment was analysed-for example, linear, laminated, diffuse, dusty, microgranular, or flaky in the stratum corneum, and cytoplasmic or pericellular, diffuse, microgranular, speckled, or flaky in the stratum spinosum and the stratum basale. The labelling of other histological structures of the oesophagus-for example, nuclei, basement membrane, smooth and striated muscle, was not recorded in this work.

\section{OTHER SERUM ASSAYS}

The total IgG was determined by radial immunodiffusion $^{22}$ using IgG-HC NOR Partigen immunodiffusion plates purchased from Behring (Malburg, FRG). The IgM RF titre was obtained by a modification of the Waaler-Rose method ${ }^{23}$; a titre of 1/64 was considered positive. Antinuclear antibodies were determined by indirect immunofluorescence on cryostat sections of mouse liver. Anti-single-stranded DNA (ssDNA) antibodies were assayed by Farr's method. ${ }^{24} \mathrm{C}$ reactive protein was determined by nephelometric assay with 'NA latex C reactive protein reagent' obtained from Behring (Malburg, FRG). Circulating immune complexes were detected by the procedure described by Zubler and Lambert. ${ }^{25}$ Total complement was evaluated by its haemolytic activity and $\mathrm{C} 3$ and $\mathrm{C} 4$ complement fractions by nephelometric assay with specific antisera obtained from Behring (Malburg, FRG).

\section{DATA ANALYSIS}

Statistical analyses were performed with home made software on a BM60 computer (Bull-Micral, Massy, France). Each variable was analysed within each group of patients: distribution, mean, standard deviation, median, range. After variance comparison, mean differences were tested with Student's $t$ test for the Gaussian variables and with MannWhitney's U test for the other variables. Similarly, correlations were sought using either BravaisPearson's or Spearman's rank correlation coefficient. A $\chi^{2}$ test was used to compare percentages. The diagnostic value of antikeratin antibody detection was assessed by computing various diagnostic indices according to the following classical formula, in which true positives (TP) were patients with RA with a positive test, false positives (FP) were controls with a positive test, true negatives (TN) were controls with a negative test, and false negatives (FN) were patients with RA with a negative test. Sensitivity $(T P /(T P+F N))$ and specificity (TN/ $(\mathrm{TN}+\mathrm{FP})$ ) allowed the intrinsic value of antikeratin antibody detection in RA to be assessed. The positive predictive value-that is, the probability of the diagnosis (TP/(TP+FP)), and the negative predictive value-that is, the probability of the diagnosis exclusion (TN/(TN+FN)), depending on RA prevalence, allowed the usefulness of the test to be determined in the actual clinical conditions of diagnostic use.

\section{Results}

All 528 serum samples were assayed for IgG and IgM antibodies to rat oesophagus. The antibodies of both classes were analysed histologically by morphological typing of the labelling in each compartment of the epithelium (stratum corneum, stratum spinosum, stratum basale) and semiquantitatively by grading of the fluorescence intensity separately in the three compartments. For both IgG and IgM antibodies, most serum samples belonging to all the diagnostic groups, labelled the three epithelial compartments, but with large interindividual variations in both morphological labelling pattern and fluorescence intensity (Fig. 1).

\section{HISTOLOGICAL ANALYSIS OF IGG AND IgM ANTIBODIES TO RAT OESOPHAGUS E P I T H E L I U M \\ $\operatorname{Ig} G$ antibodies}

From the labelling of the stratum corneum and stratum spinosum produced by IgG antibodies, four typical patterns were distinguished (Table 2); two predominated. Intense, regular, linear, laminated labelling restricted to the stratum corneum was obtained almost exclusively with RA sera. Weak, diffuse, cytoplasmic labelling of the stratum basale and the stratum spinosum associated with weak and diffuse labelling of the stratum corneum was produced by numerous serum samples belonging to every diagnostic group (Fig. 1E). Besides these two predominant forms, we also found, but rarely, two other patterns: intense, linear, laminated labelling of the stratum corneum associated with equally intense, diffuse, cytoplasmic labelling of the stratum spinosum. This was produced by only four serum samples (Fig. 1C). Lastly, intense, diffuse, cytoplasmic labelling restricted to the stratum spinosum was given by only two sera (Fig. 1D). These two last patterns were independent of disease. In many cases pericellular labelling of the stratum basale, isolated or superimposed on these various patterns, was found. This morphological analysis placed a high proportion of serum samples $(90.7 \%)$ in four histological classes. The other serum samples $(9.3 \%)$ produced labelling patterns intermediate between these four types. The more frequently found showed laminated but weak labelling of the stratum corneum associated with 
equally intense diffuse cytoplasmic labelling of the two other epithelial compartments. Because of the obvious high disease specificity of the exclusive labelling of the stratum corneum, and because of the existence of intermediate patterns including labelling of the stratum corneum, a semiquantitative estimation of its fluorescence intensity was carried out to determine the anti-stratum corneum antibody (or antikeratin antibody) titre-like value necessary for a diagnosis of RA.

\section{IgM antibodies}

In contrast with IgG antibodies, labelling of the various epithelial compartments by IgM antibodies did not distinguish a pattern for RA. The stratum corneum labelling was more or less laminated but always irregular and heterogeneous: dusty or microgranular, whatever the fluorescence intensity. The stratum spinosum and stratum basale were often stained, generally with a weak, microgranular, speckled, or flaky pattern (Fig. 1F). Although no pattern specific for RA was identified, semiquantitative analysis of the stratum corneum fluorescence intensity was performed to determine whether high titre IgM antikeratin antibodies were specific for RA or for any other disease.

SEMIQUANTITATIVE ANALYSIS OF IgG

AND I GM ANTI-STRATUM CORNEUM

ANTIBODIES OR ANTIKERATIN

A N T I B O D I E S

$\lg G$ antikeratin antibodies

All along the fluorescence intensity scale, IgG antikeratin antibodies were detected in $97.2 \%$ of sera from all the diagnostic groups (Fig. 2A). The ? mean value of IgG antikeratin antibodies was much higher in RA sera than in non-RA sera ? however (Mann-Whitney $U$ test $=6.23 ; p<10^{-8}$ ) Furthermore, the fluorescence intensity was re $\frac{\bar{c}}{\bar{N}}$ stricted to low values with the controls (non-RA) $\vec{\sigma}_{\overrightarrow{0}}$ whereas it extended all along the scale, from 0 to̊ $7 \cdot 75$, with RA sera, showing that high titre IgGon antikeratin antibodies are specific for RA (Fig. 2A) $\overrightarrow{0}$ For each IgG antikeratin antibody semiquantitative value the diagnostic sensitivity and specificit $\vec{\omega}$ were computed. The resulting curves showed that specificity increased rapidly up to a fluorescence intensity of 1.50 (Fig. 2B). At a fluorescences intensity of $1.50,1.75$, and 2.00 the specificity wase $95.43 \%, 98 \%$, and $99.14 \%$ and the sensitivity $56 \cdot 18 \%, 47 \cdot 75 \%$, and $43 \cdot 26 \%$, respectively (Table 3). At fluorescence intensities higher than $3 \cdot 25 \%$ although the sensitivity became weaker than $20 \% \overrightarrow{-}$ the specificity reached $100 \%$. Thus high titre IgCD antikeratin antibodies were found to be pathogno응 monic for RA. For all further statistical analyses we chose 2.00 as a threshold because it gave a specificity greater than $99 \%$ without serious loss of sensitivity Above this threshold, the four sera giving a nofin RA-specific pattern (Table 2) were excluded, âd $^{\circ}$ thus only three false positive sera remained $(0 \cdot 8 \%$ of non-RA sera): 1 systemic lupus erythematosus (2.00), 1 ankylosing spondylitis $(2 \cdot 25)$, and 1 Paget's disease (3.25). Moreover, IgG antikeratin anti® bodies were found to enhance the probability of RAD diagnosis from $33.71 \%$ (prevalence of $\mathrm{RA}$ in ouf

Table 2 Distribution of $R A^{*}$ and non-RA sera in histological classes according to the intensity and morphological pattern. of labelling of the stratum corneum and stratum spinosum of the rat oesophagus epithelium

\begin{tabular}{|c|c|c|c|c|c|}
\hline \multirow{2}{*}{$\begin{array}{l}\text { Epithelial } \\
\text { layer }\end{array}$} & \multirow[t]{2}{*}{ Intensity } & \multirow{2}{*}{$\begin{array}{l}\text { Pattern of } \\
\text { labelling }\end{array}$} & \multicolumn{3}{|c|}{ Number (percentage) of sera } \\
\hline & & & $\overline{R A}$ & Non-RA & Total \\
\hline $\mathrm{SC}^{*}$ & Intense & Linear & & & \\
\hline SS $^{*}$ & Weak & Diffuse & $65(36 \cdot 5)$ & $3(0 \cdot 9)$ & 69 (13.1오 \\
\hline SC & Weak & Diffuse & & & $\frac{1}{0}$ \\
\hline SS & Weak & Diffuse & $78(43 \cdot 8)$ & $326(93 \cdot 1)$ & 404 (76.5 年 \\
\hline SC & Intense & Linear & & & \\
\hline SS & Intense & Diffuse & $0(0)$ & $4(1 \cdot 1)$ & $4(0.8)$ ల్ల \\
\hline SC & Null or weak & Diffuse & & & \\
\hline SS & Intense & Diffuse & $0(0)$ & $2(0 \cdot 6)$ & $2(0.4)$ \\
\hline \multicolumn{3}{|c|}{$\begin{array}{l}\text { Miscellaneous intermedi- } \\
\text { ate patterns }\end{array}$} & $35(19 \cdot 7)$ & $15(4 \cdot 3)$ & $49(9 \cdot 3)$ 尔 \\
\hline \multicolumn{2}{|c|}{ Total $(100 \%)$} & & 178 & 350 & 528 \\
\hline
\end{tabular}



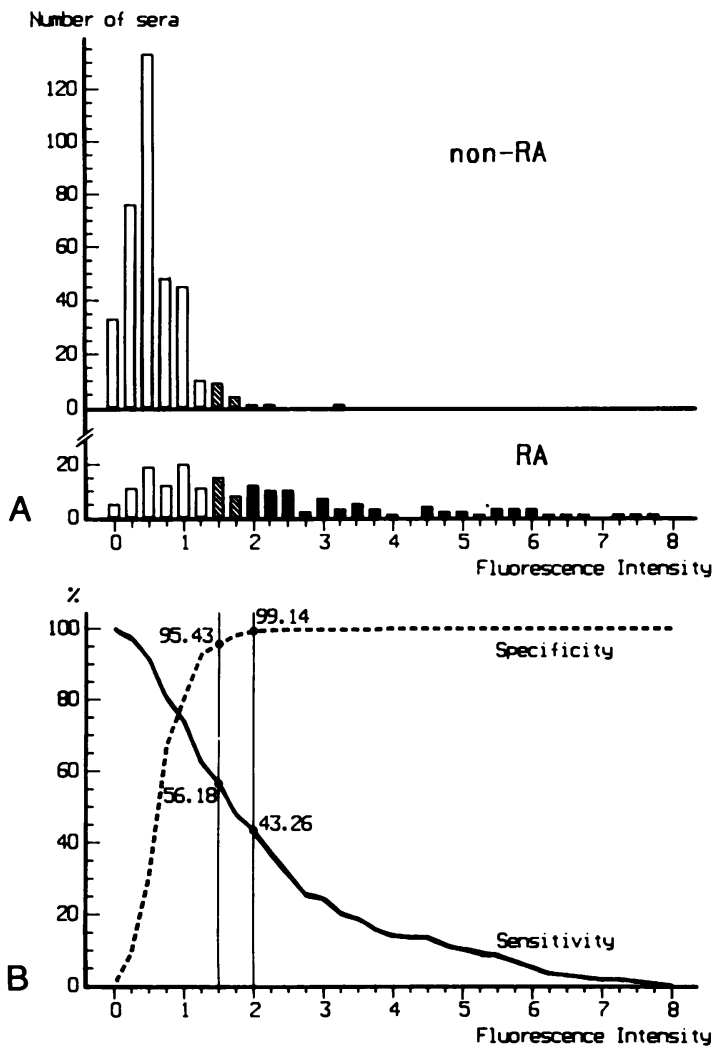

Fig. 2 Fluorescence intensity distribution, diagnostic sensitivity and specificity of IgG anti-stratum corneum antibodies (antikeratin antibodies). (A) Distribution of rheumatoid arthritis (RA) and non-RA sera according to their IgG antikeratin antibody titre-like fluorescence value. The bars show the number of serum samples for each level on the semiquantitative scale of fluorescence intensity. Empty bars: from 0 to 1.25; hatched bars: from 1.50 to 1.75; filled bars: from 2.00 to 8.00 . (B) Sensitivity (continuous line) and specificity (dashed line) were computed from the distribution above. Vertical lines show the thresholds of fluorescence intensity (1.50 and 2.00) which allowed specificities of more than $95 \%$ and more than $99 \%$ respectively, to be reached.

sample) to $96 \cdot 25 \%$ (positive predictive value). In contrast, the probability of RA diagnosis exclusion was only slightly increased, from $66.29 \%$ (prevalence of non-RA sera) to $77.46 \%$ (negative predictive value).

\section{IgM antikeratin antibodies}

All along the fluorescence intensity scale, IgM antikeratin antibodies were detected in $83.9 \%$ of the sera from all the diagnostic groups. The mean value of IgM antikeratin antibodies was higher in RA sera than in non-inflammatory control groups (MannWhitney $U$ test $=3.52 ; p<0.001$ ) but did not differ from that of other inflammatory disease groups. The ranges of fluorescence intensity were from 0 to 7.25 for RA sera and from 0 to 6.25 for the non-RA sera. When a threshold giving a $99 \%$ diagnostic specificity for RA was chosen only $4.5 \%$ of RA sera $(8 / 178)$ were detected. Thus IgM antikeratin antibodies are clearly non-disease specific.

\section{RELATIONS BETWEEN IGG ANTIKERATIN}

ANTIBODIES AND OTHER CLINICAL

AND BIOLOGICAL FEATURES OF RA

In patients with RA correlations were sought between IgG antikeratin antibodies and various other clinical and biological features (Table 4).

Sex ratio, age, and disease duration were not significantly different in the two IgG antikeratin antibody positive and IgG antikeratin antibody negative subgroups of patients. Although the percentages with classical RA (American Rheumatism Association criteria $>7$ ) were quite similar within the two IgG antikeratin antibody subgroups, subcutaneous nodules were twice as prevalent in IgG antikeratin antibody positive patients.

Among the serological variables, erythrocyte sedimentation rate and $\mathrm{C}$ reactive protein were significantly higher in IgG antikeratin antibody positive patients. Moreover, a significant correlation was found between the IgG antikeratin antibody titre and erythrocyte sedimentation rate $(r=0.203$, $p<0.05)$ and between the IgG antikeratin antibody titre and the amount of $C$ reactive protein $(r=0.305$, $\mathrm{p}<0.001)$. The mean RF titre was four times greater $(1 / 16 v 1 / 64)$ in IgG antikeratin antibody positive than in antibody negative patients. Similarly, the RF titre and IgG antikeratin antibody titre were significantly correlated $(r=0.336, p<0.001)$. Nevertheless, $34 \%$ of RF negative patients (21/61) were IgG antikeratin antibody positive. The circulating immune complex titre was significantly higher in IgG antikeratin antibody positive patients and correlated well with the IgG antikeratin antibody titre $(r=0.333, p<0.001)$. Finally, IgG antikeratin antibodies were independent of all the other studied immunological variables - that is, antinuclear antibodies and ssDNA antibodies, total amount of serum IgG, total serum complement, and $\mathrm{C} 3$ and $\mathrm{C} 4$ complement fractions.

\section{Discussion}

Since the report of Young $e t a l^{8}$ antibodies associated with RA that react with rat oesophagus stratum corneum have always been called antikeratin antibodies, ${ }^{239-17}$ probably because of their labell- 
Table 3 Diagnostic value of IgG anti-stratum corneum antibodies (IgG antikeratin antibodies). Diagnostic indices are expressed as percentages (5\% confidence interval) for three consecutive fluorescence intensity thresholds

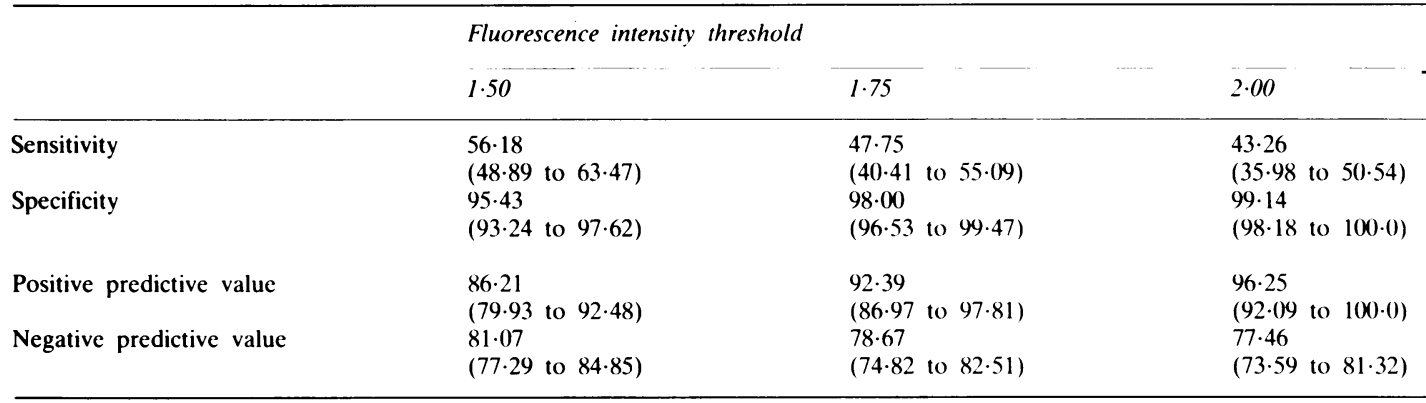

ing pattern and also because keratins are the major component of this epithelial compartment. The stratum corneum of the cornified stratified squamous epithelium of rat oesophagus, however, like the homologous compartment of human epidermis, contains, besides keratin polypeptides, a wide variety of other potentially antigenic molecules. On the other hand, we showed in a previous study, by a specific enzyme linked immunosorbent assay (ELISA), the existence of $\operatorname{IgG}$ and $\operatorname{IgM}$ naturally occurring autoantibodies directed to epidermal keratin polypeptides in all the normal human sera. ${ }^{21}$ In addition, we have investigated these autoantibodies in rheumatic diseases and have shown that they are of no diagnostic value for RA.
So, considering these various arguments and in th $\frac{V}{60}$ absence to date of any immunochemical evidence $\mathrm{og}$ the nature of the antigen recognised in rat oesophagus stratum corneum by the RA specific antibodiess we think it would be more appropriate to call thes8 antibodies anti-stratum corneum antibodies rathe $\vec{P}$ than antikeratin antibodies.

In this work we studied, in a large sample of patients with rheumatic diseases, the circulating $\varepsilon_{8}$ and IgM antibodies to rat oesophagus epitheliuto

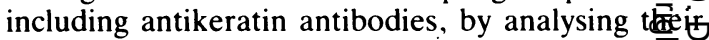
labelling pattern and evaluating their titre.

Histological analysis of $\operatorname{IgG}$ antibodies to th epithelium allowed us to describe four typical low belling patterns. Of the two found more frequentlyo

Table 4 Relation between IgG anti-stratum corneum antibodies (IgG antikeratin antibodies) and various clinical data an耳 serum variables in rheumatoid arthritis (RA). Values are given as mean (range) or number $(\%)$

\begin{tabular}{|c|c|c|c|}
\hline & $\begin{array}{l}\operatorname{Ig} G A K A * 2 \\
(n=101)\end{array}$ & $\begin{array}{l}\operatorname{Ig} G A K A \geqslant 2 \\
(n=77)\end{array}$ & $p V a$ \\
\hline No $(\%)$ of men & $18(18)$ & $14(18)$ & NS \\
\hline Age (years) & $57 \cdot 2(19-81)$ & $62 \cdot 5(35-82)$ & NS \\
\hline Disease duration (years) & $12.3(0.5-32)$ & $14 \cdot 1(1-43)$ & NS \\
\hline No $(\%)$ with classic $\mathrm{RA}$ & $62(61)$ & $51(66)$ & NS \\
\hline No (\%) with subcutaneous nodules & $18(18)$ & $27(35)$ & $0 \cdot 020$ \\
\hline $\mathrm{ESR}^{*}(\mathrm{~mm} / \mathrm{lst} \mathrm{h})$ & $39 \cdot 2(2-130)$ & $51 \cdot 4(2-130)$ & $0 \cdot 030$ \\
\hline $\mathrm{C}$ reactive protein $(\mathrm{mg} / \mathrm{l})$ & $40 \cdot 2(8-173)$ & $66 \cdot 5(9-195)$ & $0 \cdot 001$ \\
\hline IgM RF $^{*}$ (titre) & $1 / 16(1-1 / 1024)$ & $1 / 64(1-1 / 1024)$ & 0.001 \\
\hline Antinuclear $\mathrm{AB}^{*}$ (titre) & $1 / 16(1-1 / 2048)$ & $1 / 16(1-1 / 2048)$ & NS \\
\hline Anti-single-stranded DNA AB (\%) & $5.9(0-55)$ & $2 \cdot 3(0-30)$ & NS \\
\hline Circulating immunc complexes (\%) & $5 \cdot 5(0-90)$ & $9 \cdot 7(0-60)$ & 0.001 \\
\hline $\operatorname{IgG}(\mathrm{g} / \mathrm{l})$ & $14 \cdot 4(5 \cdot 5-31 \cdot 5)$ & $15.6(6 \cdot 0-21 \cdot 9)$ & NS \\
\hline Complement (\% of normal) & $109 \cdot 4(58-181)$ & $110 \cdot 0(43-160)$ & NS \\
\hline C3 (\% of normal) & $98 \cdot 0(58-158)$ & $97 \cdot 0(49-151)$ & NS \\
\hline $\mathrm{C} 4(\%$ of normal) & $115 \cdot 0(55-295)$ & $110 \cdot 0(50-210)$ & NS \\
\hline
\end{tabular}

${ }^{*} \mathrm{AKA}=$ antikeratin antibodies: $\mathrm{ESR}=$ erythrocyte sedimentation rate; $\mathrm{RF}=$ rheumatoid factor; $\mathrm{AB}=$ antibodies: $\mathrm{C3}, \mathrm{C4}=\mathrm{serum}$ complement fractions.

tThe mean differences or percentage differences between the two subgroups were tested by the Mann-Whitney $U$ test or $\chi^{2}$ tc respectively. The IgG antikeratin antibody positive subgroup of RA was defined by a stratum corneum fluorescence intensity $\geqslant 2 \cdot 0 \mathrm{C}$ 
the intense linear laminated labelling restricted to the stratum corneum was highly specific for RA, while the weak diffuse labelling of the three epithelial compartments was found in some RA sera but also in numerous non-RA sera. Of the two other typical but scarce patterns, the exclusive labelling of the stratum spinosum was of no diagnostic value, while the equally intense labelling of stratum spinosum and stratum corneum permitted discrimination between the related antibodies and the RA specific antibodies and prevented the related sera from being considered as false positives. The patterns intermediate between these typical forms could result from the simultaneous presence of antibodies of different specificities-for example, low titre RA specific IgG antikeratin antibodies and other antiepithelial IgG in the same RA sera. In these cases only the semiquantitative evaluation of the stratum corneum fluorescence intensity permitted diagnosis. This quantitative approach also allowed us to show that IgG antikeratin antibody diagnostic sensitivity and specificity were closely linked to their titre (Fig. 2B). Indeed, up to a fluorescence intensity of 1.25 the specificity was considered insufficient (less than $95 \%$ ), while from 2.25 the sensitivity became too weak for diagnostic use (less than $40 \%$ ). To obtain the best compromise between sensitivity and specificity we chose 2.00 as a threshold because it allowed a diagnostic specificity of more than $99 \%$. Thus for an individual serum a result below that threshold does not permit a diagnosis of RA to be excluded (low negative predictive value). At the threshold the diagnosis can be asserted with an error probability of $3.75 \%$ (high positive predictive value). Beyond the threshold the predictive value increases, and over a fluorescence intensity of 3.50 the test becomes pathognomonic for RA as the diagnosis can be asserted without computable error.

In contrast, IgM antibodies to this epithelium were present in almost all the serum samples with large interindividual variations in their labelling and in their titre. Moreover, no pattern specific for RA or for any other disease could be identified. Among them, IgM antikeratin antibodies, sometimes with a high titre, were found in RA as well as in non-RA sera and thus were clearly of no diagnostic value.

To summarise, the histological analysis of IgG antibodies to rat oesophagus epithelium permitted a histological pattern typical of RA specific IgG

Table 5 Diagnostic value in rheumatoid arthritis of anti-stratum corneum antibodies, so-called antikeratin antibodies, computed from studies reported since 1979. Only the studies performed on separate samples of patients were considered

\begin{tabular}{|c|c|c|c|c|c|c|c|c|c|}
\hline \multirow[t]{2}{*}{ Author } & \multirow[t]{2}{*}{$\operatorname{Ref}$} & \multirow{2}{*}{$\begin{array}{l}\text { Class } \\
\text { of } A K A^{*}\end{array}$} & \multirow{2}{*}{$\begin{array}{l}\text { Number } \\
\text { of sera }\end{array}$} & \multicolumn{4}{|c|}{ Number of positive seraltotal } & \multirow{2}{*}{$\begin{array}{l}\text { Sensitivity } \\
(\%)\end{array}$} & \multirow{2}{*}{$\begin{array}{l}\text { Specificity } \\
(\%)\end{array}$} \\
\hline & & & & $R A^{*}$ & $\begin{array}{l}\text { Other } \\
\text { rheumatic } \\
\text { diseases }\end{array}$ & $\begin{array}{l}\text { Miscellaneous } \\
\text { non-rheumatic } \\
\text { diseases }\end{array}$ & $\begin{array}{l}\text { Normal } \\
\text { controls }\end{array}$ & & \\
\hline Quismorio & 11 & $\operatorname{Ig}(?)$ & 211 & $46 / 80$ & $7 / 84$ & & $2 / 47$ & $57 \cdot 50$ & $93 \cdot 13$ \\
\hline Hajiroussou & 15 & $\lg (?)$ & 304 & $121 / 204$ & $6 / 100$ & & & $59 \cdot 31$ & $94 \cdot 00$ \\
\hline 1st groupt & & $\operatorname{Ig}(?)$ & 515 & $167 / 284$ & $13 / 184$ & $0 / 0$ & $2 / 47$ & $58 \cdot 80$ & $93 \cdot 51$ \\
\hline Young & 8 & $\operatorname{lgG}$ & 286 & $75 / 129$ & $1 / 52$ & & $0 / 105$ & $58 \cdot 14$ & $99 \cdot 36$ \\
\hline Johnson & 2 & IgG & 219 & $52 / 102$ & $2 / 47$ & $1 / 10$ & $0 / 60$ & 50.98 & 97.44 \\
\hline Scott & 9 & IgG & 165 & $36 / 99$ & $8 / 16$ & & $0 / 50$ & $36 \cdot 36$ & $87 \cdot 88$ \\
\hline Ordeig & 12 & IgG & 566 & $71 / 131$ & $7 / 266$ & $2 / 69$ & $0 / 100$ & $54 \cdot 20$ & 97.93 \\
\hline Kataaha & 13 & $\lg G$ & 205 & $39 / 72$ & & $0 / 40$ & $0 / 93$ & $54 \cdot 17$ & $100 \cdot 00$ \\
\hline Youinou & 14 & IgG & 1072 & $156 / 421$ & $5 / 91$ & $13 / 313$ & $6 / 247$ & 37.05 & $96 \cdot 31$ \\
\hline Meyer & 16 & IgG & 227 & $67 / 122$ & $3 / 75$ & & $1 / 30$ & 54.92 & $96 \cdot 19$ \\
\hline Kirstein & 17 & $\operatorname{lgG}$ & 297 & $73 / 156$ & $0 / 61$ & & $2 / 80$ & $46 \cdot 79$ & $98 \cdot 58$ \\
\hline \multicolumn{2}{|l|}{ 2nd group ${ }^{\dagger}$} & IgG & 3037 & $569 / 1232$ & $26 / 608$ & $16 / 432$ & $9 / 765$ & $46 \cdot 19$ & $97 \cdot 17$ \\
\hline \multirow{3}{*}{ This study $\ddagger$} & & & & $100 / 178$ & $16 / 350$ & & & $56 \cdot 18$ & $95 \cdot 43$ \\
\hline & & IgG & 528 (b) & $85 / 178$ & $7 / 350$ & & & 47.75 & 98.00 \\
\hline & & & (c) & $77 / 178$ & $3 / 350$ & & & $43 \cdot 26$ & $99 \cdot 14$ \\
\hline
\end{tabular}

*AKA = antikeratin antibodies; RA = rheumatoid arthritis.

In the first two studies antikeratin antibodies were assayed using non-IgG specific antibodies, whereas in the second group of eight studies, as in this study, IgG specific antibodies were used. The tested sera were divided into four classes: RA, various other rheumatic diseases, miscellaneous non-rheumatic diseases, and normal control sera. Sensitivities and specificities were computed for each study and for each group of studies.

$\ddagger a, b, c$ : results computed according to three fluorescence intensity thresholds: (a) $1 \cdot 50$, (b) $1 \cdot 75$, and (c) $2 \cdot 00$. 
antikeratin antibodies to be identified and thus allowed us to exclude some sera which would have been considered as false positive. The semiquantitative analysis permitted the high diagnostic relevance of IgG antikeratin antibody detection in RA to be confirmed and its diagnostic indices to be objectively established. Both analyses showed that IgM antikeratin antibody detection cannot constitute a diagnostic test.

Almost all the international reports on antikeratin antibodies (Table 5) since the first work of Young et al, asserted their diagnostic relevance for RA. ${ }^{2} 38$ 10-17 Only Scott et al considered these antibodies to be 'of very limited value'. ${ }^{9}$ In all these studies the assayed serum samples were considered positive based on criteria which sometimes included the labelling pattern characteristics 911121517 but which never referred to a definite fluorescence intensity level. Moreover, even the authors who performed a rough evaluation of the fluorescence intensity 815 or an antibody titration by limit dilution $^{3} 11$ 14-16 did not consider the labelling produced by the so-called negative sera and always regarded it as background fluorescence. So, the diagnostic sensitivity and specificity were imposed on the investigators by their previously chosen detection threshold. This is probably the main explanation of the differences in sensitivity and specificity they reported, but the variations in the assay procedures they used or in the composition of the patient samples they analysed, or both, can alse explain these discrepancies. When antikeratin antic. bodies were investigated with non-IgG specifie secondary antibodies able to detect all the $\mathrm{im}^{\text {? }}$ munoglobulin classes ${ }^{11} 15$ the percentage of positive RA sera reached $58.8 \%$, while the false positives were found to exceed $6 \%$. This can be explained bo the simultaneous detection of IgM and IgG antio keratin antibodies, which can be present together iक⿱乛龰 an RA serum, as shown by Quismorio et al ${ }^{11}$ and Ordeig et $a^{12}$ and confirmed throughout our serumsamples. Therefore, to define the true diagnostie value of IgG antikeratin antibody detection on very large number of sera from various origins, the studies in which only the antikeratin antibodieso belonging to the IgG class were considered as RAdo specific $^{2} 89$ 12-14 1617 were analysed together with our results. In these studies the mean diagnostico sensitivity of IgG antikeratin antibodies was $46.1 \%$ 윽 ranging from $36.4 \%$ to $58.1 \%$, which is roughly similar to the variation of sensitivity induced in thif study by a slight threshold variation. On the othe? hand, if one excludes the results of Scott et al, ${ }^{9}$ wh ${ }^{\mathbb{8}}$ found a high percentage of false positive sera $(12 \%)$ the diagnostic specificity in the other studies yas. always better than $96 \%$. Moreover, the megato percentage of false positives was found to varg slightly between the different control subgrous so $1 \cdot 26 \%(9 / 715)$ of the normal sera, $3 \cdot 70 \%(16 / 432)$ of the miscellaneous non-rheumatic sera, and onle

Table 6 Relations between anti-stratum corneum antibodies, so-called antikeratin antibodies, and clinical data and serun $\overline{\overline{\bar{S}}}$ variables in rheumatoid arthritis, reported since 1979. Only variables studied by at least two authors are included ${ }_{-}^{*}$

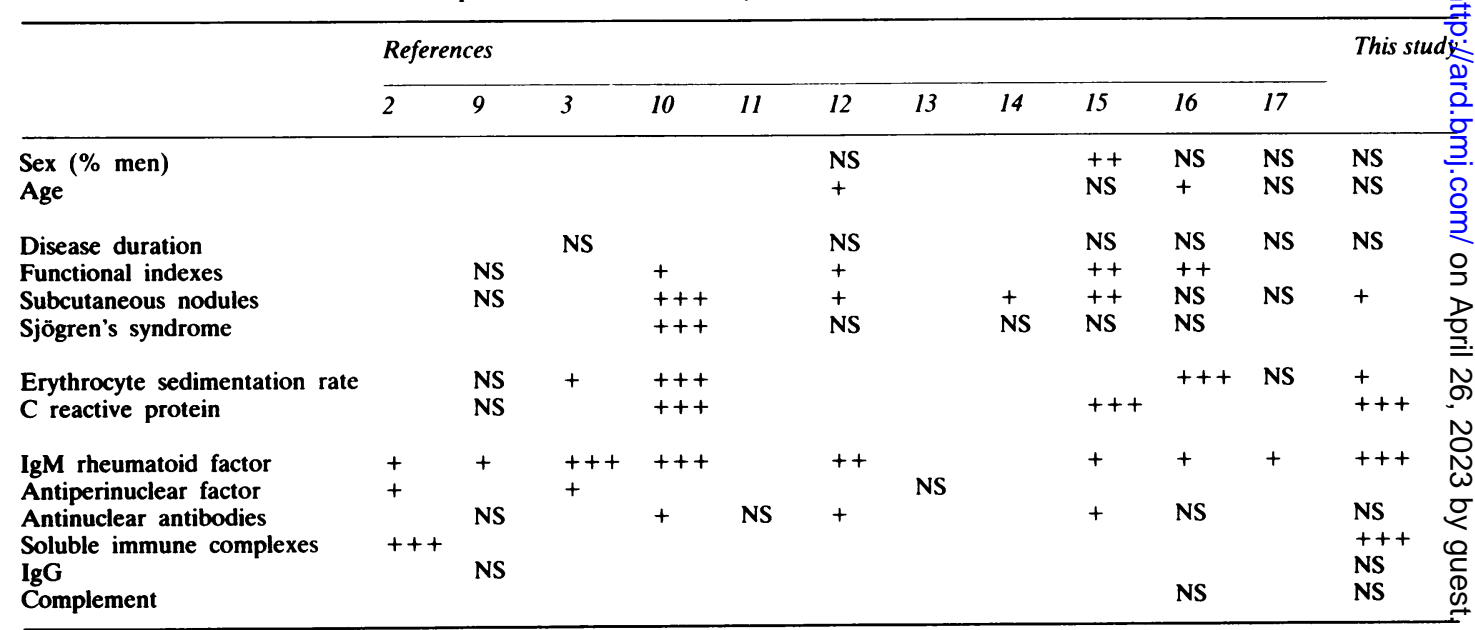

*For each variable a higher value in the antikeratin antibody positive subgroup or a correlation with antikeratin antibody titre, or both, was sought.

Significance of the tests is given as $+=p<0 \cdot 05 ;++=p<0 \cdot 01 ;+++=p<0 \cdot 001$; NS=non-significant; blank=not tested. 
$3.04 \%(18 / 592)$ of the rheumatic non-RA sera. In our study the percentage of false positives among the rheumatic non-RA sera ranged from $4.57 \%$ to $0 \cdot 86 \%$ when the chosen threshold ranged from 1.50 to $2 \cdot 00$.

The relations between IgG antikeratin antibodies and other clinical and serological indexes of RA investigated in our series (Table 4) were analysed together with those reported in previous studies (Table 6). From the whole series of results we compared IgG antikeratin antibody detection with other diagnostic tests for RA and attempted to determine whether the antikeratin antibody positive patients belonged to a particular subgroup of RA, with regard to the other indexes of the disease.

The incidence and titre of IgG antikeratin antibodies were found to be significantly correlated with IgM RF by all the authors who investigated such a correlation, ${ }^{39101215-17}$ and in both respects we agree with these results. As in previous studies, ${ }^{3121617}$ however, we showed that a large percentage of RF negative RA $(34.43 \%)$ can be diagnosed by $\mathrm{IgG}$ antikeratin antibody detection. Antiperinuclear factor was also found to be correlated with IgG antikeratin antibodies by Johnson et al and by Miossec et al. ${ }^{23} \mathrm{RF}$, and to a lesser degree antiperinuclear factor, have some diagnostic use in $\mathrm{RA},{ }^{-3}$ but the high number of false positive sera, especially among the other connective tissue diseases, ${ }^{8}$ reduces the diagnostic relevance of these two factors. IgG antikeratin antibody detection, though less sensitive, is highly RA specific and thus is most important in diagnosis of the disease. Thus detection of IgG antikeratin antibodies is the most useful of these three tests for the diagnosis of RA. Indeed, if IgG antikeratin antibodies are present, especially at a high titre, the diagnosis of RA is clearly established.

On the other hand, we found no correlation between IgG antikeratin antibodies and antibodies to nuclear antigens, whereas in previous studies ${ }^{9-12} 1516$ such a correlation was shown, but only by three authors. ${ }^{10} 1215$ The other autoantibodies investigated (to cartilage, smooth muscle, thyroid, gastric parietal cells, mitochondria, reticulin, vimentin) were never found to be related to IgG antikeratin antibodies. ${ }^{911} 15$ Lastly, we confirmed ${ }^{9}$ that IgG antikeratin antibodies vary independently of total serum IgG concentration. In this study, as found previously, various biological and clinical indexes related to disease severity or activity, or both, were found to be associated with IgG antikeratin antibodies. We confirmed that IgG antikeratin antibodies are associated with increased erythrocyte sedimentation rate re $^{10}$ and especially with increased concentrations of $\mathrm{C}$ reactive protein, ${ }^{10} 15$ and we showed in agreement with Johnson et al, ${ }^{2}$ a correlation between IgG antikeratin antibodies and circulating immune complexes. Among the extra-articular features of the disease, we found a higher incidence of subcutaneous nodules in the IgG antikeratin antibody positive patients, as reported by most other authors. ${ }^{10} 121415$ An association with Sjögren's syndrome was also found but only by Mallya et al..$^{10}$ Finally, a significant association between IgG antikeratin antibodies and various functional criteria such as Steinbrocker's index ${ }^{28}$ was also shown. ${ }^{10121516}$ All these correlations suggest that IgG antikeratin antibodies are probably associated with the most severe or active forms of RA. Nevertheless, in agreement with Meyer et al ${ }^{16}$ the total haemolytic complement activity, like the C3 and $\mathrm{C} 4$ fractions, was found to be normal in both the IgG antikeratin antibody positive and negative RA subgroups.

Disease duration was never found to be related with the incidence of IgG antikeratin antibodies, ${ }^{3} 12{ }^{15-17}$ and this was confirmed in our series by both incidence and titre. This independence may indicate, as suggested by Ordeig et al, ${ }^{12}$ that IgG antikeratin antibodies appear at the beginning, indeed may even precede the disease, and thus may be useful for the early diagnosis of RA. Nevertheless, only further longitudinal studies will be able to define the value of IgG antikeratin antibodies in predicting the development of RA.

We think that indirect immunofluorescence detection of antikeratin antibodies should be used more widely. To ensure interlaboratory reproducibility, however, the following procedure should be used. The middle third of rat oesophagus must be used as substrate as it allows the best diagnostic sensitivity and specificity to be obtained. ${ }^{9} 11$ IgG antikeratin antibodies must be detected with secondary antibodies specific for human IgG to prevent the simultaneous detection of non-RA-specific IgM antikeratin antibodies. The histological labelling pattern must be analysed to identify false positive sera (Fig. 2C). Evaluation of the titre, either semiquantitatively by fluorescence intensity or by a dilution titration method, is also necessary because the specificity depends on the titre, and also the classification as positive or negative of sera which do not present a typical histological pattern of labelling would become possible. Each laboratory will easily be able to establish its own reference standards with two samples of well characterised sera from patients with or without RA. A specific immunoassay is awaited, but meanwhile the various groups trained in this aspect of immunorheumatology could colla- 
borate to select reference sera, thus leading to international standardisation.

In conclusion, the diagnostic value of antikeratin antibodies has been assessed by 11 research groups working with 4080 patients, including 1694 with RA, coming from 10 places in five countries-that is, from genetically heterogeneous populations. Analysis of all the results obtained by us and other workers under comparable technical conditions $^{2} 812-141617$ shows that the mean diagnostic sensitivity of $\mathrm{IgG}$ antikeratin antibody detection is better than $46 \%$ and the mean specificity is near $98 \%$. This test must, therefore, be considered as the most specific biological criterion for the diagnosis of RA, which actually becomes pathognomonic when IgG antikeratin antibodies are present in a high titre. IgG antikeratin antibodies are more specific for RA than are RFs, and, moreover, allow a high percentage of RF negative $\mathrm{RA}$ to be diagnosed. Furthermore, IgG antikeratin antibodies may have some prognostic significance as the subgroup of RA defined by high IgG antikeratin antibody titres seems to correspond to more severe or more active forms of the disease. It remains to be determined whether IgG antikeratin antibodies are present at a weak titre in all human sera and only increased in RA or whether they result from a synthesis specific for patients with RA. In the same way their possible pathogenic significance remains, to date, totally unexplored.

We thank M F Isaia, M P Rué, and J P Basile for their valuable technical assistance. We also thank Dr M Stebenet. Laboratoire de Biochimie II, Dr F Oksman and Dr Smilovici. Centre Régional de Transfusion Sanguine, Hôpital Purpan. Toulouse. for providing some of the biological data. Supported in part by grants from the Association pour la Recherche contre le Cancer. the Ligue contre le Cancer, and the Conseil Régional de Midi-Pyrénées.

\section{References}

I Nienhuis $\bar{R}$ L F, Mandema E, Smids C. A new serum factor in patients with rheumatoid arthritis, the antiperinuclear factor. Ann Rheum Dis 1964; 23: 302-5

2 Johnson G D, Carvalho A. Holborow E J, Goddard D H. Russell G. Antiperinuclear factor and keratin antibodies in rheumatoid arthritis. Ann Rheum Dis 1981: 40: 263-6.

3 Miossec P. Youinou P. Le Goff P. Moineau M P. Clinical relevance of antikeratin antibodies in rheumatoid arthritis. Clin Rheumatol 1982: 1: 185-9.

4 Menzel J, Steffen C, Kolarz G. Eberl R. Frank O. Thumb N. Demonstration of antibodies to collagen and of collagenanticollagen immune complexes in rheumatoid arthritis synovial fluid. Ann Rheum Dis 1976: 35: 446-50.

5 Andersen I. Andersen P. Graudal H. Smooth-muscle antibodies in rheumatoid arthritis. Acta Pathologica et Microbiologica Scandinavica. Section C. Immunology 1980; 88: 131-5.

6 Osung O A. Chandra M. Holborow E J. Antibodies to intermediate filaments of the cytoskeleton in rheumatoid arthritis. Ann Rheum Dis 1982; 41: 69-73.

7 Senecal J L, Olivier J M. Rothfield N. Anticytoskeletal autoantibodies in the connective tissue diseases. Arthritis Rheum 1985; 28: 889-95.
8 Young B J J, Mallya R K. Leslie R D J. Clark C J M. Hambli T J. Anti-keratin antibodies in rheumatoid arthritis. $\mathrm{Br} M e d$ के 1979: ii: $97-9$.

9 Scott D L. Delamere J P. Jones L J. Walton K W. Significance of laminar antikeratin antibodies to rat oesophagus in rhe matoid arthritis. Ann Rheum Dis 1981; 40: 267-71

10 Mallya R K. Young B J J. Pepys M B. Hamblin T J. Maç $B E W$. Hamilton E B D. Anti-keratin antibodies in rheumato arthritis: frequency and correlation with other features of tho disease. Clin Exp Immunol 1983: 51: 17-20.

11 Quismorio F P. Kaufman R L. Beardmore T. Mongan E §ొ Reactivity of serum antibodies to the keratin layer of ratt oesophagus in patients with rheumatoid arthritis. Arthrit? Rheum 1983: 26: 494-9.

12 Ordeig J. Guardia J. Diagnostic value of antikeratin antibodiese in rheumatoid arthritis. J Rheumatol 1984: 11: 602-4.

13 Kataaha P K. Mortazavi-Milani S M. Russel G. Holborow E Anti-intermediate filament antibodies, antikeratin antibody and antiperinuclear factor in rheumatoid arthritis and infectiolo mononucleosis. Ann Rheum Dis 1985: 44: 446-9

14 Youinou P. Le Goff P. Colaco C B, et al. Antikeratin anti bodies in serum and synovial fluid show specificity for rheumato toid arthritis in a study of connective tissuc diseases. Anto Rheum Dis 1985: 44: 450-4.

15 Hajiroussou V J. Skingle J. Gillett A P. Webley M. Significance of antikeratin antibodies in rheumatoid arthritis. $J$ Rheumat $\&$ 1985: 12: 57-9.

16 Meyer O. Fabregas D. Cyna L. Ryckewaert A. Les anticorp

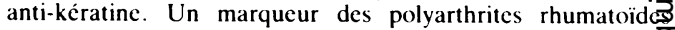
évolutives. Rev Rhum Mal Osteoartic 1986: 53: 6(1)-5.

17 Kirstein H. Mathiesen F K. Antikeratin antibodies in rheumatoid arthritis. Scand J Rheumatol 1987; 16: 331-7.

18 Ropes M W. Bennett G A. Cobb S. Jacox R. Jessar R A. \$) revision of the diagnostic criteria for rheumatoid arthritis. Fudl Rheum Dis 1958: 9: 175-6.

19 Arnett F C, Edworthy S M. Bloch D A. et al. The Ame rica Rheumatism Association 1987 revised criteria for the classifica tion of rheumatoid arthritis. Arthritis Rheum 1988: 31: 315-2P

20 Serre G. Vincent C. Mauduyt M A. Solcilhavoup J P. Planel bह Morphologic. quantitative and cytoenzymologic studies \& synoviocytic and monocytic cells in synovial fluid. Analyticatin and Quantitative Cytology 1984; 6: 227-37.

21 Serre G. Vincent C. Viraben R. Soleilhavoup J-P. Natural Ig and IgM autoantibodies to epidermal keratins in normal huma疋 sera. I. ELISA titration, immunofluorescence study. J Invext Dermatol 1987: 88: 21-7.

22 Mancini G. Carbonara A O. Heremans J F. Immunochemicâ quantitations of antigens by single radial immunodiffusion? Immunochemistry 1965: 2: 235-45.

23 Podliachouk L. Eyquem A. Jacqueline F. Le diagnostic de polyarthrite chronique évolutive par agglutination de globule rouges humains sensibilisés. Ann Inst Pasteur Immunol 1958 94: $659-62$.

24 Farr R S. A quantitative immunochemical measure of tho primary interaction between I BSA and antibody. $J$ Infect Dis 1958: 103: 239

25 Zubler R H. Lambert P H. ${ }^{12 s} 1 \mathrm{Clq}$ binding test for solubli immune complexes. Ann Rheum Dis 1977: 36: 627-30. N

26 Serre G. Vincent C. Viraben R. Soleilhavoup J P. Autoantibodies to keratins in normal human sera, systemic lupuf erythematosus. rheumatoid arthritis and psoriasis. Eur J Cliñ Invest 1985: 115: A36.

27 Serre G. Vincent C. Lapeyre F. Fournié B. Soleilhavoup J ए Fournić A. Anticorps anti-stratum corncum d'oesophage do rat. autoanticorps anti-kératines et anti-épiderme dans la pol: arthrite rhumatoide et diverses affections rhumatologiques Intérêt diagnostique, aspects fondamentaux. Rev Rhum Măl Osteoartic 1986: 53: 607-14.

28 Steinbrocker O. Traeger C H. Batterman R C. Therapeut $\bar{Q}$ criteria in rheumatoid arthritis. JAMA 1949: 140: 659-62. 